\title{
"When the orthodox went away": histories of displacement and extermination on the Polish/Belarusian border
}

Aimée Joyce

\begin{tabular}{|c|c|}
\hline Date of deposit & 16082018 \\
\hline Document version & Author's accepted manuscript \\
\hline Access rights & $\begin{array}{l}\text { Copyright ( The Institute for Ethnographic Research. This work is } \\
\text { made available online in accordance with the publisher's policies. } \\
\text { This is the author created, accepted version manuscript following } \\
\text { peer review and may differ slightly from the final published } \\
\text { version. }\end{array}$ \\
\hline $\begin{array}{l}\text { Citation for } \\
\text { published version }\end{array}$ & $\begin{array}{l}\text { Joyce, A. (2019). "When the orthodox went away": histories of } \\
\text { displacement and extermination on the Polish/Belarusian border. } \\
\text { Anthropological Quarterly, 92(2), } 427-450 .\end{array}$ \\
\hline $\begin{array}{l}\text { Link to published } \\
\text { version }\end{array}$ & https://muse.jhu.edu/article/729304 \\
\hline
\end{tabular}

Full metadata for this item is available in St Andrews Research

Repository at: https://research-repository.st-andrews.ac.uk/

\section{St Andrews Research Repository}




\section{"When the Orthodox Went Away": Histories of Displacement and Extermination on the Polish/Belarusian Border}

\section{Introduction}

Koden is a small town on the eastern Polish border with Belarus and each year at the end of July it abounds with apples. Apple trees grow with abandon, on private land, public land, and those uncertain spaces between the two. It was near the end of my research in the town that the apples began to ripen on the trees. People, especially children, picked them with little concern for ownership. One local teenager, who I caught leaning over my fence to pull an apple from the tree in the garden, went so far as to inform me that apples were "common property".

There was only one place in the town where the apples were left alone. Halfway down the dust road behind my house was a small plot of land enclosed on three sides by roads, and with a small path worn diagonally across it. By early August the apples from the trees on this plot of land littered the ground, rotting; no one collected them. I was a little surprised to learn that no one told the children not to pick these apples, in fact no one spoke about this plot of land at all. Children learned by example, for as long as they remembered their elders had left these apples to rot every season. It was an inaction that created the sense that something on this site was not to be remembered, that it was a place to be avoided, and that the story of the site was not to be told.

The rotting apples of Kodeń were not the only space of silence in the town. In early November while taking photographs in the shared Roman Catholic, Eastern Orthodox cemetery I noticed three low mounds of earth among the graves in front of me. One knoll was marked with an iron patriarchal cross but the others were bare. Looking around I noticed that 
there were other mounds of earth like this throughout the Eastern Orthodox side of the cemetery; some were unmarked, some had small bundles of plastic flowers or decaying wooden crosses lying on them. When I left the cemetery, I pointed out the mounds of earth to the caretaker and asked if they were graves, and if so why they were in such disrepair. Without looking up from his work the gravedigger told me they were graves: "when the Orthodox went away there was no one left to look after them". It was clear there would be no further conversation.

This paper explores these two silent spaces. I argue that the current rise of right wing nationalism in Poland utilizes a set of nested historical erasures and silences, yet these silences are evoked and maintained in the spaces of absence that pockmark the landscape of the eastern Polish borders. As Trouillot shows, all history making is about selective acts of remembering and forgetting, and close attention to specific "unthinkable" histories reveals how power infuses the process of history making (1995:29). In this paper, I discuss two "unthinkable" historical events, in an attempt to demonstrate how their continued silent presence in the town of Koden is shaped by current state practices of memory making. In the Polish case, the authorized historical record produces a homogenous model of Polish identity by excluding specific histories of dispossession and destruction, including Akcja Wisła ${ }^{l}$ and the Holocaust, which I will discuss here. Yet, the unspeakable continues to haunt the present imaginary, and even to organize it in specific ways. Memories of specific events are spread unevenly across places; "there is no place that is not haunted by many different spirits hidden there in silence, spirits one can "invoke" or not... Haunted places are the only ones people can live in" (De Certeau 1984:108). I therefore explore how local people engage and evoke these silent spirits via the fragmented and intricate materiality of these haunted spaces and through acts of remembrance and forgetting. As I will show, these practices are an attempt to 
negotiate a complex multi-ethnic history of conflict and cohesion, yet they also reveal that some conflicts are more unsayable than others.

\section{Affective Spaces and Loud Silences on the Eastern Polish Border}

Both the apple tree plot and the disappearing Orthodox ${ }^{2}$ graves, are what Yael Navaro-Yashin calls affective spaces (2012:24). They are spaces where a trace of history remains stubbornly silent, yet these spaces generate affect when they become entangled in human mediations. Neither the people nor the spaces alone create an affective geography, but "both produce and transmit affect relationally" (Navaro-Yashin 2009:14). Navaro-Yashin's work on affective spaces bridges the divide between the ideational and material, she demonstrates that the "phantasmatic has an object-quality, and vice versa" (2012:10). It is an approach that privileges neither the subjective nor affective and instead focuses on the entangled inner and outer worlds and the dialectically formed "affect-subjectivity continuum" (ibid:24). NavaroYashin's work helps answer an important question facing any anthropologist working in areas of the world sufficed with silences. How can anthropologists speak about silence, what is not there, and what is not said? Navaro-Yashin's work demonstrates that by paying close attention to the relationships between people, material worlds, affect and social organization, the anthropologist can bring silences and absences into focus ${ }^{3}$. In affective spaces absence and silence are commonly encountered as traces. Valentina Napolitano has looked back into the early years of anthropology to excavate a long anthropological history of working with traces (2015). Napolitano demonstrates how these traces - the material forms of condensations of stories remembered and forgotten, social, and political alterities - are particularly suited to an ethnographic methodology that pays careful attention to slippages, lapses, and ephemera, "that privileges ways of free association rather than concentrated meaning." (2015:51). While studying what is not said may be at the edge of the 
anthropologists capacity, these silences can be traced by paying close attention to the material world that makes present absences.

In this paper, I first want to pay close attention to the nested silences that shape Koden. As Trouillot has pointed out absences embodied in the sources from which history is built are not neutral (1995: 48). Rather these material absences are created and as such "are not mere absences but mentions or silences of various kinds" (ibid). In this sense I wish to argue that there are two types of silence relating to and reflecting what philosopher Patrick Fuery, has identified as two types of absence (1995). There is true silence, a silence we may never even know exists, it is like an absence that "exists outside of any relation to presence" (Fuery 1995:5). Then there is silence that is loud, like a negative space or secondary absence, we know there is something unspoken, because its shape is there, in everything that is said, and in the spaces that materially manifest the absence of something: "Something is absent because it is not present, but the significant detail is that the absent something is figured as potentially present" (ibid:1). In these cases narration is a vital component of figuring what is felt as missing. Navaro-Yashin argues that affect is transmitted through objects but "this affect is mediated and qualified by the knowledge that the people who come into contact with them have about the context for the[se] objects" (2012:212). Affective responses are generated in interactions between humans and materialites. A loud absence can be generated by a gap in the material world where we know something should be. But it can also be generated when there is a conspicuous silence or refusal to engage with a powerful material presence.

I suggest that the silences that are enacted in Koden are incomplete, relational, and importantly deeply material: while the silences are linked to the complex histories of displacement and destruction these histories have left multiple material traces in the 
landscapes of the eastern borders of Poland. These traces are, as Trouillot argues, anthropologically interesting as they offer insight into what has been silences in the process of the state developing a coherent and useful history of the region (1995: 26, 29). In Koden, therefore, loud silences operated in two distinct ways. Firstly, they can indicate something is not fully known, drawing attention to the gaps in the authorized history of the area, and thus asking important questions about current national practices of historicity. On the other hand, these loud silences can indicate the things that cannot be said but that "set the stage for future historical narratives" (Trouillot, 1995: 29) in Kodeń. In each case the act of silencing operates slightly differently, but the outcome is the same. Silence is deployed to smooth over the conflicts that are engendered in the everyday activities and living history of Koden.

Drawing on Trouillot's argument that specific histories are silences by countering them with generalities of an opposing view I frame the silences in Kodeń within national practice of identity formation. Since Prawo i Sprawiedliwość ${ }^{4}$ (PiS) took power in November 2015 there has been increasing awareness about a move to the right in Polish Politics, both inside and outside the country, and since this paper was originally written it seems these changes are now being discussed on the world stage ${ }^{5}$. In the 2011 Parliamentary Elections, which fell during my fieldwork period from 2010/11, Platforma Obywatelska ${ }^{6}$ (a Pro-EU, liberal conservative party) were re-elected to a second term, becoming the first party to do so since 1989. Poland had just completed its first turn at the EU presidency, it had avoided the EUwide recession of 2009, and was the co-host of the UEFA Euro 2012 (the Union of European Football Associations' Championship, held every 4 years by different host Nations). In the following election in 2015, however, PiS connected to a large portion of the Polish population (mainly rural) who did not feel the effect of the country's economic stability and growth. Since PiS has returned to government they have evoked a politics centered on the restoration of a traditional, sovereign, Catholic Poland capable of protecting its interests 
against "liberal" reformers both inside and outside the country. The PiS platform spurns the vision of the state as a political unit, in favor of a nativist version of the state, as an entity united by cultural, ethnic and religious homogeneity (Kaczynski 2011). This vision of the state requires that certain histories and experiences remain silent, while other historical events are loudly commemorated.

The stakes of remembering and forgetting are particularly high in Kodeń and the wider eastern border region. Eastern Poland's 20th century was perforated with a series of organized displacements and genocides, each intended to expose and eliminate perceived ethnic interlopers from the historically multi-ethnic, multi-linguistic, and multi-religious territory (Snyder 2003). The Polish state has an ambiguous relationship with the multi-ethnic nature of its eastern borders (Zarycki 2013), an ambiguity that is not unique to it. In Notes on the Balkans Sarah Green addresses the ambiguity of borders by focusing on the Greek/Albanian frontier region of Epirus and its inhabitants (2005). Ambiguity rests on the contradiction of being "just" (opposed to "pure") Greek (Green 2005:83). On the one hand, the residents of Epirus with the Greeks who live in the interior are "just Greek", the same as everyone else despite their place on the border. On the other hand, being "just Greek" implies that the residents of Epirus just about qualify as Greek due to their place on the edge of the country (ibid). A similar contradiction is managed locally in Koden through the "fantasy" of the borderland (Aretxaga 2005:106). The fantasy of the borderland operates as a mode of existence and a model for coexistence, and neither operation can be detangled from the other. This could also be understood as a practice of "border work", the constant daily tasks that accompany the movement between conflict and co-existence that Madeline Reeves described in the Ferghana Valley (2014). Both border work and the fantasy of the borderland attempt not to see the border only through the perspective of the state. Rather they focus on the 
people who live along borders and the work they are part of and its role in spatializing or imaging the state at its frontiers ${ }^{7}$.

Kodeń sits on the border with Belarus and is just an hour's drive from the Ukrainian border. Further south, this eastern borderland area is referred to as the Kresy. Kresy is an important and heavy word in Polish - while it directly translates as borderland, it has become strongly associated with the corridor between Ukraine and Poland, an area that has been the site of ethnic conflict since World War I and has passed through the hands of many different political polities during its existence (Hann 1998, Hann \& Magocsi 2005). Yet the people of Kodeń more commonly use the word pogranicze to discuss their border location.

Buchowski, distinguishes three ways of talking about borders in Poland, as "border line [linia graniczna], a border [granica] and a borderland [pogranicze]" (2004:9). Pogranicze indicates the zone around the border, and the cultural characteristics that have become associated with that zone over time (Buchowski 2004:9). The use of pogranicze then embraces a form of reality that exists between the conscious and unconscious actions and desires of state and non-state actors (Aretxaga 2005:106). An enduring element of this fantasy along Poland's north-eastern borders is the centrality of the encounter with the other. The Polish poet and author, Krzysztof Czyzewski, himself a borderlander, argues that this encounter is the key element of the borderland identity. "Only when one confronts, when one meets with Otherness in this place of intermingling, does one's identity appear.” (2002:20-21).

However, this fantasy of intermingling others and selves connects to a larger national fantasy of the eastern borderlands, the Myth of the Kresy. The agreement between Poland and the USSR, which established the 1945 border (based on the earlier Soviet/Nazi 1939 border) entailed a drastic change to the borders that had existed prior to the Second World War. Between 1919 and 1939 Poland's eastern lands extended to cover territory beyond the 
Curzon line, in what is now Ukraine, Belarus and Lithuania. After World War II Poland gained territories to the west and lost a large amount of territory in the east ${ }^{8}$. These "lost" areas in the former eastern borderlands are the foundation of the Myth of the Kresy. The "Kresy" here may specifically refer to the lost interbellum eastern territories, but it is connected to a larger sense of lost empire. Prior to partition the Polish-Lithuanian Commonwealth stretched far beyond the Curzon line. The Myth of the Kresy, is premised on a belief that Poland has a historical right to the lost eastern territories (Zarycki 2013). In this myth the Kresy is imagined as a lost peaceful, multicultural rural Arcadia, ultimately guided by enlightened Polish values. The key actor in the myth is the Polish speaking, Roman Catholic citizen of the Polish-Lithuanian Commonwealth. The rest of the population that made up this region, the Belarusian, Yiddish, Russian and Ukrainian speakers, the Eastern Orthodox, Greek Catholic, Jewish and Tatar Muslims are presented as the "others" to be tolerated and civilised (ibid). The myth of the Kresy remains deeply connected to how the current eastern Polish borders are imagined. Current opinions on East Poland within the government, regional development agencies and right-wing discourse draw on the historic link between east Poland and Russia, as a neighbor and colonial power. They anticipate an amount of cultural, linguistic, and religious plurality in this area, but ultimately this is seen as "exotic" and not fully incorporated in the national image of the Polish citizen. Instead the "others" along the eastern borders represent a "disturbing sense of closeness or kinship" to the Uncanny Slavdom (ibid).

The local fantasy of the borderland and fraternal selves and others, relies on a specific understanding of tolerance, where difference is at once acknowledged and then minimized. This model is expressed well in one resident of Koden, Hela's insistence "for me it's no matter whether you are, for example, Jewish or a Jehovah's Witness, come in and I will offer you tea, thank you." (Joyce 2017:10). The irony here is that these differences must matter to 
Hela, or else she would not feel the need to mention the variety of guests she could receive. This everyday tolerance that underpins the fantasy of the borderland is enabled by practices of forgetting and silencing. Hela is only able to suggest offering a cup of tea to a Jewish neighbor by ignoring the traumatic and violent legacy of the Holocaust in the town. However, not all differences can be minimized, some histories of difference cannot be spoken without rupturing the illusion of coexistence. Therefore, the practice of coexistence is based on accepting the silencing of specific groups and histories. A similar practice operates on

multiple levels in Poland. At the level of local government, the production of the bucolic idyll of easy-going rural pluralism vital to the tourist program is premised on the rich "multicultural" heritage sites that punctuate the eastern borders ${ }^{9}$. Yet it excises from the stories of these places the violent events that that caused them to become "heritage", and implicitly relies on a model of citizenship whereby non-Polish speaking or non-Roman Catholic people are presented as "exotic Others". At the national level, it seems that increasingly, silence and forgetting play a vital role in authorizing a particularly chauvinistic form of historical memory, premised on the illusion of an extant fully Roman Catholic Poland.

\section{Orthodox Graves}

The eastern borders of Poland have a minority Eastern Orthodox Christian population, and most medium to large sized towns have a small Orthodox Church and cemetery. There was an Orthodox graveyard in Kodeń, but since the 1920s it had been shared with the Roman Catholics. A path ran through the graveyard, splitting it in two. Two gates had been added to the wall that surrounded the site, one on either side of the central path. One gate was topped with the Latin cross. The other by the suppedaneum cross. This was the Orthodox side (although in truth, Orthodox and Roman Catholic graves were unruly and sometimes 
appeared on the "wrong" side of the informal divide), there were some older traditional iron Orthodox graves. But mostly the Orthodox graves were made of stone like the Roman Catholic ones. The most obvious difference was that the Orthodox graveyard always seemed emptier than the Roman Catholic one during my time in the field.

The rows of graves on the Orthodox side were frequently interspersed with the mounds of earth I described in the introduction, indicating forgotten burials. Even the graves still marked showed the signs of ruination. Large sections of the small iron fences that traditionally surround Eastern Orthodox graves were missing. Graves were overgrown with weeds, or fallen wooden crosses were left leaning against the headstones of other graves. And yet the cemetery was well kept, the stone graves were cleaned and on many of the disappearing graves people had left small plastic floral tributes. Ethnographer Robert Hertz argued in 1909 (and more recently Taussig 2001) that death is only a temporary exclusion from the social world of the living. The dead are quickly reincorporated into the world as ancestors, ghosts or historical figures (Hertz 2013 [1909]). However, to do this, their bonds with the living must continue. The objects that we place on graves, their headstones, iron markers, flowers, do more than stand for the dead, they animate them. These acts of commemoration manifest our attitudes towards the role the dead play in the world, and ensure the dead play their assigned role (Hallam \& Hockey 2001). The small floral tributes and evidence of regular care and maintenance demonstrate that people still visit these graves and care for them. Yet the material remnants and the emptiness at the heart of the Orthodox graveyards pointed out that something had happened, some big event had suddenly interrupted the lives of the Orthodox in this area.

Parts of Kodeń's history only appear as gaps in the narrative, unexplained incidents or material fragments. The disappearing graves were one such material fragment, related to a 
very specific puzzling incident: the moment in 1947 "when the Orthodox went away". Haukanes addresses a similar avoidance of macro-historical events in the telling of biographies in the Czech Republic (2006). She points out that history is only alluded to in accounts of normal life by her respondents, such as when they remark that 1968 was the year someone went away. By refusing to name any actual event, such as the 1968 protests, people detach themselves from traumatic histories they may be implicated in or affected by (Haukanes 2006). It is interesting to examine why Kodeń's attitude to its history manifests in this way. Particularly in light of Ania Witeska-Mlynarczyk contrary assertion that in the memoryscape of a mid-sized Polish city "there was always a date, a historical event to refer to, and ... a personal story was always contextualized through a reference to a political episode" (2013:63). In other words, personal and collective memory were orientated through their relationship to specific nationally acknowledged historical events. Once we look a little closer at narratives of the past in Koden we notice the gaps and exclusions in local historical memory are not entirely obscured. Rather the onus is on the listener to learn to listen for, not only to, the stories (Cruikshank 1998). A lot is imparted outside of the actual words, through how the story is selected and the context of its telling (ibid:44). This approach connects well with Napolitano's concept of traces: here the phrase "when the Orthodox went away" is the trace of a larger set of condensed stories, remembered and forgotten fragments of history. The presence of these traces interrupts the authorized historical narrative. The traces of other, silenced stories, present in the material world of Koden prevent the edited history of the region being accepted completely as fact (Trouillot, 1995: 29).

The moment "when the Orthodox went away" from Kodeń coincides with the first large-scale state organized resettlement program since the end of World War II, Akcja Wisła. Between the Partition of Poland in 1795 and the formation of the Second Polish Republic in 1920, Kodeń was under the influence of several foreign states, most notably the Russian empire 
from 1815 until 1915 (Wandycz 1975:74). Its economy was devalued and the use of Polish language discouraged. Throughout this period Tsarist Russia encouraged the ascendancy of the Orthodox faith, and Roman Catholic churches were handed over to the Orthodox Church. The Roman Catholic population was increasingly pressured to join the Orthodox faith. The Greek Catholic minority was forcibly assimilated into the Orthodox Church, and those who refused were imprisoned or murdered (Keleher 1995). This left a residual resentment toward the lay Orthodox Christians, and thus shaped the Roman Catholic majority's treatment of the Orthodox minority.

In 1938 the Polish state instigated Operation Polonization, which declared it was time for "polonizacji prawosławia" the polonization of the Orthodox (APL, UWL WSP:430).

Primarily the aim was to convert Orthodox Christians to Roman Catholicism, and thus avoid them falling under the influence of Ukrainian or Russian agents. Alongside this, "inactive" Orthodox churches were to be closed or changed to Roman Catholic churches (Mich 1994:101). This provision eventually led to the burning of many Orthodox churches along the Bug river, and according to Papierzyńska-Turek, the demolition successfully diminished the Orthodox faith in the area, weakening its influence and significantly affecting the number of local Orthodox families (1989:373).

The tensions between the two faiths did not ease during the World War II period. From 1943 to 1944, the Ukrainian Insurgency Army (UPA) carried out its bloody activities in Volhynia and Eastern Galicia (Hryciuk 2002:101-117, Piotrowski 1998:242-258). From 1944 to 1946 the Soviet Russian State organized a series of transnational repatriations, or "population exchanges. About 780,000 Poles and Jews out of Ukraine, apparently to curtail the actions of the UPA. In the same period an estimated 450,000 Ukrainians were moved from Poland into SSR Ukraine (Hann 1998). By the conclusion of the transnational relocations the Polish State 
estimated there were 74,000 Ukrainians left in Poland, the numbers were closer to 200, 000 (Misiło 2013:43).

The Polish state had already developed plans to "disperse" these "remnants" and the assassination of the Polish Defence Minister in 1947, allowed them to announce that "As soon as possible, an Operational Group should be organized, to form a plan for the complete extermination of the remnants of the Ukrainian population in the south-eastern border region of Poland among other things" (Snyder 1999:109). This meant "resettl[ing] Ukrainians and mixed families in the regained territories, without forming any tight clusters and no closer than 100 kilometers to the border" (Snyder 1999:108). The resettlement plan called Akcja Wisła, (known in English as Operation Vistula) began in 1947.

Akcja Wisła focused on three provinces Rzeszów, Lublin, and Cracow, and over the course of four months approximately 150,000 people (30,000 families) were relocated (Kersten 1991:392). During the operation, soldiers would surround a village and a senior officer would enter and read out a list of those to be resettled; the selected families would then be given a few hours to pack twenty-five kilograms of luggage. After this, the villagers would be marched to a halfway stop where they would later board cattle freight trains to the Recovered Territories in the west (Misiło 2013:222-225). It is important to note that the ethnicity of those relocated was generally determined by the presence or absence of a $u$, standing for Ukrainian, on their Nazi-issued papers. This identification had been haphazard, most often based on religious affiliation, local hearsay, or convoluted notions of "blood inheritance" (Snyder 2003:198).

Koden was part of the Lublin province, at the northern corner, and older residents of the town recall the expulsion of the Orthodox, but only the Orthodox residents discuss it. Families left behind homes, filled with the possessions they could not carry. They abandoned their 
decorative churches. They left behind their dead, in graves marked with iron crossed and bordered by small iron railings. In a time of intense resource shortages, the iron from the Orthodox graves was quickly removed and by the time the Orthodox could return to Koden the graves of their ancestors had already begun to disappear, turning into mounds of earth. The disappearance of the Orthodox graves during the post Akcja Wisła period is not an accidental event: forced forgetting is a purposeful act, as is remembering. The removal of the iron from Orthodox graves may have been driven by economic necessity, but a failure to replace the markers, or maintain the graves were both deliberate acts of silencing. At stake is the difficulty of living with a history in which the ascendency of the Roman Catholic population is based on the expulsion of their Eastern Orthodox Christian neighbors.

Families and individuals returned to the east of Poland many years later, to find their homes and churches occupied and a lingering silence about the time the "Orthodox went away". The affective power of the disappearing graves relies on their near-ruination, and on the continuing silences in local, regional and national post-War histories. Akcja Wisła moved family's cross country, it led to pockets of Eastern Orthodox Christianity in areas of Western Poland with no historical link to the Eastern Orthodox faith (Wylegała 2015). It created Roman Catholic churches with strange interior and exterior, design flourishes that have no place in the Roman Catholic decorative tradition. The Orthodox forced to leave in 1947 did not always come back. The iron markers had been removed from these abandoned graves, no families had returned to reclaim or revive them. The disrepair gave way to empty patches and plots in the graveyard, dead bodies with no family names. The gaps and silences in the local memoryscapes are complex, voluble, and tangible. Would the silence around Akcja Wisła exist without the empty plots of land in the graveyard? Yes it would, but the material presence of these absence spaces ensures that this silence remains present in the everyday life of the town, remains loud. 
The connection between the silencing of Akcja Wisła and the absent graves also informs the actions of the local Orthodox population. It is reflected in the manner local people tried to teach me about the period and its aftermath: at the beginning of Orthodox Easter, the time when the dead are traditionally remembered, my landlady asked me if I would record her reading a poem. In the poem, a man looks back on the moment he leaves his village as a young boy sitting on top of a wagon filled with the possessions of his family and their friends. Within the poem are details of how Akcja Wisła was organized, how long families had to pack their goods, how long the journey took, but the operation is never addressed by name. When she reached a stanza about the use of animal wagons to transport the families, my landlady began to cry and asked me to turn off the recorder. The next day we went together to visit the graves. We visited most of the graves in the cemetery and left flowers on some of the empty plots. My landlady had not directly addressed Akcja Wisła with me. Instead she had found some more fragments she could draw my attention to, so that I could begin to experience the story of Akcja Wisła, but she knew there were elements of the story that could not be told.

The poem was also an emotive reminder that the Orthodox population did not simply "go away", they were forcibly removed. Importantly, this removal echoes another more unspeakable forced removal. The silence that surrounds Akcja Wisła is premised on a louder, more unspeakable silence: the Holocaust. At moments in the stories that surround Akcja Wisła we can see quite plainly the traces that the Holocaust has left across the affective spaces of East Poland. The insistence on remembering that the Orthodox travelled by cattle car is important for this reason. Anna Wylegała, refers to the memories of travel on cattle freight trains during Akcja Wisła as a "topos of memory", a conventional theme or topic (2015:474). In its repeated appearance in the stories of Akcja Wisła, she detects a rhetorical use, a short hand for arguing that this group was treated worse than any others (ibid). 
However, I think that the memory of travel by cattle trains is the result of the nested silences in this region of Poland. The Orthodox community was not the first moved like this, like animals rather than people. During World War II, the local Jewish population was taken away in the same types of trains. Referring to the Cattle Cars ties these two silences together. It neatly demonstrates that an unspoken act of violence does not simply disappear, it continues to exist in particular material objects and in the use of these objects elements of that foundational act repeat in later violent incidents, animating how local people speak about history.

What becomes apparent in any discussion of "when the Orthodox went away" is that there is no complete and straightforward narrative. Instead there are fragments of personal stories, material remnants, family memories, art and silences that are constantly articulated and rearticulated to try and evoke the affective experience of the local Orthodox minority and forge a way of knowing about the Akcja Wisła period. Traces highlight the "limits of renarrativization of the past", however silences in the historical record can also "bite back" through the trace "in forms of mimetic repetitions, obsessions and excesses" such as the cattle cars and rotting grave markers (Napolitano 2015: 58-60). Speaking of Poland's complex history, Frances Pine has advocated a shift from the privileging of voice to a perspective that instead considers the silences, absences, fragments and traces in the lived present (Pine in discussion with Navaro-Yashin, 2013). Similarly, Nichanian has written about the impossibility of voice in the case of histories without archives (2009). Perhaps Napolitano expressed the rational for anthropological reservations about narrativizing hidden histories best (2015). Traces may indeed be the condensation of multiple stories, but these stories "cannot be comprehended through a given language of the present" (Napolitano 2015:58) as they are material forms that are "unmediated by conclusive structures of meaning" (Napolitano 2015:62). These stories exist on the edge of the representable and non- 
representable, in the place between the flesh and the environment. They are as much felt as they are spoken (ibid). Meyer embraces the "incomplete, elusive, slippery and awkward" trace as a way into what he calls the "relational ontology of absence" (2012: 107). He is interested in how absent or silent events "come to matter" (ibid: 103). Citing John Law, he argues that silences and absences become apparent in the "provisional relations of representation", in a flow of "movements, ... attachments, ...translations and representations (ibid:107). Similarly Pine, Navaro-Yashin, Napolitano and Nichanian all argue the imposition of "a voice" (or the clumsy attempt to "give voice") to unrecorded histories can flatten or give a false sense of coherence or singularity to these historical events and can emplace meaning where there is none. Instead, by bringing the traces of silences and absences into focus, anthropologists can question teleological national historical narratives, without replacing them with equally prescriptive alternative histories.

\section{Jewish Graves}

By the halfway point of my fieldwork, people spoke openly to me about many of the violent events that punctured the town preferred history of cohesion: Akcja Wisła in 1947; about the Congress Poland period of history (1815-1915) and the destruction of Roman Catholic Churches; about the 1938 polonization projects; about the 1874 Pratulin Greek Catholic martyrs; about the bloody atrocities of the UPA. Behind all the talk of these violent events and confrontations there was the trace of a darker and even more unspeakable tragedy always implied. Even so, until I questioned why one of the town's roads was still unpaved, no one told me anything about the fate of the local Jewish population during World War II.

One day in March as I was walking along the dust road behind my house with a local amateur historian I asked why the road we were on was unpaved. After a moment of silence, he informed me that when the Nazi's came through the area they tore up the headstones from the 
Jewish graveyard and used them to pave this road, so that their tanks could make it across the sandy soil. The road was infrequently used and no one was eager to tarmac it, on the one hand, to avoid further desecrating the headstones, and on the other, because if the road was left undisturbed there was no way of knowing if the story of the headstone paved road was true. The headstones were probably still there under the road, but it was just possible they were not. My companion then offered to take me to the demolished cemetery. When I first visited Kodeń a year before my fieldwork started, I was told by a colleague in Warsaw that the town had a Jewish Cemetery, but despite an exhaustive search of the town I found no trace. Once I was shown the location of the graves, I asked some of my respondents about the site. Initially people were taciturn, I was told that "there is nothing there" or "it is unused, empty land".

But the site was not empty, it was covered in apple trees.

The site of the destroyed Jewish graveyard was bounded to the west by the dirt road under which the headstones of its inhabitants potentially still rested. Not a single headstone remained on the site, the earth had no suspicious hollows or mounds. The only indication that something was amiss with this small plot of land was the local refusal to eat the apples that grew on it. The local historian who first showed me the site suggested that it extended across one of the roads to another plot that on weekends contained a livestock market. He implied that this was intended as a final slight to the exterminated Jewish population. While his assertion has found its way to some of the online Jewish Genealogy sites, I could find no evidence of this, and other residents of the town rebutted it with passion.

After some time, I had some limited success corroborating the cemetery's existence and position with a few of Koden's residents, always on the proviso that I told no one in the town that they had told me. Yet, most people continued to tell me with conviction that there was no 
Jewish Cemetery in Kodeń, that I must be confusing the town with Sławatycze, which has an official memorial to its Jewish gravesite. It is difficult to know if people were unwilling to talk to me about the traces of local Jewish heritage or if they really did not know about these remnants. Part of the reason the silence around the Jewish population's history and annihilation is troubling is because the fragments and gaps which might challenge it are temporally precarious: they may not have existed twenty or even fifteen years ago, when Poland was still grappling with the implications of Polish anti-Semitism during World War II, and they could potentially cease to be apparent within a few generations, given recent Government legislation ${ }^{10}$. criminalizes statements made anywhere in the world that ascribe guilt for wartime Nazi atrocities to the Polish state or nation

One of PiSs favored slogan's is “we're rising from our knees” (Bucholc 2016), and as part of this initiative, the party has advocated a move away from what they believe is a "pedagogy of shame". Or put another way, a move to expunge the records of Polish complicity in the Holocaust from the authorized historical narrative. This is clear in the recent actions of PiS representatives particularly, the introduction of a laws criminalizing statements that suggest the Polish nation is in any way guilty for Nazi war-crimes ${ }^{11}$, outlawing the phrase "Polish death camps"12 and an increasing emphasis on the non-Jewish victims of the Holocaust ${ }^{13}$, particularly in the now state influenced Gdansk World War II museum ${ }^{14}$.

After all this time, I still struggle to speak about the Jewish population in Koden in my own work. Occasionally, when still in the field, I would hear a frightening story about collaboration or the actual deportation of local Jews to ghettos in larger towns, but they were isolated tales. I could never get corroboration; often the people who originally told me the stories refused to repeat them or gave me another version of the story on the second telling. More poignantly I never heard of tales of local Jewish culture as a living tradition prior to 
World War II (Weinryb 1973). What traces I could find, the stories of relocation via cattle car, the apple trees, the dust road, were all subtle and easy to dismiss if one was so inclined. Mostly there was silence. The silence served to efface the violence of the Holocaust while also sowing the seeds of epistemological uncertainty. The refusal to let the destruction of the Jewish communities in eastern Poland into conversation demonstrates that memories are not simply communicated through historical events that everyone remembers. The historical events are carefully chosen to adhere to a publicly accepted narrative of the past further entangling memory and history in Kodeń.

The uncertainty that I encountered in the town is reproduced in the available literature on Jewish life in Koden. There is a drive in the diasporic Jewish community to find and reconstruct the evidence of European Jewish life before the Shoah. Bourguignon speaks of the "unprecedented effort to collect and preserve information" and the resulting difficulty of making sense of the more than 57,000 interviews gathered by Survivors of the Shoah Visual History Foundation, among others (2005: 66). In these projects accuracy is valued, and family chronicles are filled with dates and numbers. Nevertheless, the annihilation of European Jewish heritage attempted by the Nazi's has often left historians dealing with the realm of epistemological vagueness. As such the quest for certainty and accuracy, the desire for numbers and dates can often produce contradictory information. The "Encyclopedia of Jewish Life Before and During the Holocaust" identifies a Jewish settlement Koden by the second half of the eighteenth century (2001:604). However, according to some online Jewish Genealogy and Holocaust Chronicle sites, the first Jewish inhabitants arrived in $1623^{15}$. What is generally accepted, is that by 1861 there were 722 Jewish residents in the town.

Deteriorating economic conditions, and the activities of the Bund and Agudat Israel Zionist movements meant that the population dropped from 541 Jewish residents in 1921 to 273 by 1939, and this number included a group of 105 people from Krakow (Spector \& Wigoder 
2001:604). By the end of World War II Kodeń no longer had a Jewish community - in 1940, Kodeń's Jewish community had been confined to a ghetto. In 1942, the town's Jewish population was expelled to Międzyrzeca Podlaski and to Treblinka death camp shortly afterwards (ibid). The town's synagogue and beth midrash were both destroyed soon after. The gravestones removed from the cemetery to pave the road were never unearthed, and the site was left abandoned. The site of the synagogue and beth midrash were both build over.

However, if the history of Kodeń's Jewish population has been silenced by the destruction of their material world, why do children still refuse to eat the apples that grow in the razed graveyard? I suggest that the silence about the Holocaust in Koden does not mask the trauma of that great tragedy or desensitize the locals to it. Nadine Fresco has argued that the stories Holocaust survivors tell their children are a "screen of words", designed to shield them from the "black hole" of the Shoah ${ }^{16}$. They are just another form of silence; the same words, the same tales, repeated endlessly and devised to say nothing. Yet these stories do not obliterate the memory of the Holocaust, instead they "outline an invisible object enclosed in an impossible evocation" (Fresco 1981). Marianne Hirsch demonstrates that rather than shielding the black hole, the silence of the survivors acts as a traumatic fixation (2001:29). Talking about photographs from the Holocaust she explains that "It is only when [the photographs] are redeployed, in new texts and new contexts, that they regain a capacity to enable a postmemorial working through" (ibid). Trouillot has argued that "the focus on the past often diverts from the present injustices" (1995: 150). To combat the real and sometimes debilitating results of the manipulation of history we need to engage actively in the present alongside working to reshape narratives of the past (ibid). So long as silence is used to screen off the trauma of the Holocaust, that trauma remains and cannot be worked through. The Holocaust was a critical event, it broke apart what came before and "instituted a new modality of historical action which was not inscribed in the inventory of that situation" (Das 
1995:5). The residents of Kodeń may not speak about the extermination of the Jewish population during World War II, but they cannot forget it. The children of Koden do not need to be told not to touch the apples in the demolished graveyard, they do not even need to be told that the trees are growing on a Jewish graveyard. The complete silence of their elders is instructive.

\section{Conclusion}

My fieldwork was bookended by the release of two films about Polish minorities that provoked strong responses in the country. Róża (Rose) addressed the violence experienced by a Masurian ${ }^{17}$ woman in the Recovered Territories at the end of World War II; Poklosie (Aftermath) was a fictionalized retelling of the ramifications of Jedwabne pogrom, whose director/writer was stirred by the controversy surrounding Jan T Gross's book Neighbors (2001). Both movies received critical praise, while they were excoriated by nationalist and far right websites and figures. Privately many of the people I worked with expressed a deep ambivalence about the films.

The films separately address each of the loud silences that Koden's tolerant existence was built on: the Shoah and the forced relocations of the post war period. The basic demographics of Poland have changed drastically in the last century. World War II and the horror of the Holocaust led to the decimation of eastern Poland's numerous Jewish communities (Spector \& Wigoder 2001). Then the brutal ethnic cleansing the UPA conducted in Volhynia and Eastern Galicia, and the Polish state-organized resettlement programs scattered and diminished the Eastern Orthodox Christian community (Hann 1996, Snyder 1999). While the Polish state currently takes an approach to historical memory that emphasizes this ethnic and religious conflict, it also insists that it was fermented by "outsiders" (Sawicka 2016). 
In the introduction, I suggested that rise of right wing nationalism in Poland relies on a nested set of historical erasures and silences to produce a homogenous model of Polish identity, which it can loudly defend. I also noted the contradictory nature of the silences in Kodeń. On the one hand, silence is deployed as a technique to negotiate a complex multi-ethnic history of conflict and cohesion. On the other, there are many slippages and material ephemera that draw attention to the silences. The careful excavation of these "mimetic repetitions, obsessions and excesses" (Napolitano 2015: 60) begins to undo the authorized historical narrative. In this way silence can have another meaning: it is not just a way to construct teleological national histories, it can also disrupt them.

\section{Bibliography}

Archiwum Państwowe w Lublinie (APL), Urząd Wojewodzki Lubelski (UWL); Wydział Społezno-Polityczny (WSP), Reference number 430.

Aretxaga, B, 2005. States of Terror: Begoña Aretxaga's Essays. Reno: University of Nevada.

Bourgois, P, 2005. "Missing the Holocaust: My Father's Account of Auschwitz from August 1943 to June 1944”. In Anthropological Quarterly 78(1): 89-123.

Bourguignon, E, 2005. "Memory in an Amnesic World: Holocaust, Exile and the Return of the Suppressed" In Anthropological Quarterly 78(1): 63-88.

Bucholc, M., 2016. The Polish Constitutional Crisis 2015-16: A Figurational Perspective. Human Figurations, 5(2). 
Buchowski, M. 2004. “Granica a uprawianie antropologii - uwagi wstĊpne”, In, PolskaNiemcy. Pogranicze kulturowe i etniczne / Poland-Germany. Cultural and Ethnic Border. Edited by Buchowski, M. \& A Brencz. Wroclaw: Polskie Towarzstwo Ludoznawcze.

Charnysh, V. and E. Finkel (2018). "Rewriting History in Eastern Europe: Poland's new Holocaust law and the politics of the past". Foreign Affairs https://www.foreignaffairs.com/articles/hungary/2018-02-14/rewriting-history-eastern-europe (last accessed 04/12/2018)

Cruikshank, J. 1998. The Social Life of Stories: narrative and knowledge in the Yukon Territory. Nebraska: University of Nebraska Press.

Das, V. 1995 Critical events. Cambridge: Oxford University Press.

De Certeau, M. 1984. The Practice of Everyday Life. Berkeley: University of California Press.

Fresco, N 1984. "Remembering the Unknown" Nouvelle Revue de Psychanalyse No. 24

Fuery, P. 1995. The Theory of Absence: Subjectivity, signification and Desire. Greenwood Press.

Green, S. 2005. Notes from the Balkans; locating marginality and ambiguity on the Greek Albanian Border. New York: Princeton University Press.

Gregg, M. and Seigworth, G.J. eds., 2010. The Affect Theory Reader. Duke University Press.

Gross, J.T., 2001. Neighbors: The destruction of the Jewish community in Jedwabne, Poland. Princeton University Press. 
Hallam, E. and Hockey, J., 2001. Death, memory and material culture. Bloomsbury Academic.

Hann, C. 1996. "Ethnic Cleansing in Eastern Europe; Poles and Ukrainians beside the Curzon Line". Nations and Nationalism: 2(3):389-406.

Hann, C. 1998. "Postsocialist Nationalism; Rediscovering the Past in Southeast Poland". Slavic Review 57(4): 840-63.

Hann, C., and P.R. Magocsi, eds. 2005. Galicia: a multicultural land. Toronto: University of Toronto Press.

Haukanes, H. "Telling Lives; Autobiography and History after Socialism”. In Changes in the Heart of Europe; Recent ethnographies of Czechs, Slovaks, Roma and Sorbs. Edited by T McCajor Hall and R Reed. Münster: Ibidem Verlag, 2006.

Hertz, Robert. Death and the right hand. Vol. 4. Routledge, 2013 [1909].

Hirsch, M. (2001). Surviving images: Holocaust photographs and the work of postmemory. The Yale Journal of Criticism, 14(1), 5-37.

Hryciuk, G. 2002. “Akcje UPA przeciwko Polakom po ponownym zajęciu Wołynia i Galicji Wschodniej przez Armię Czerwoną w 1944 roku” (pp: 101-117). In Antypolska akcja OUNUPA 1943-1944: fakty i interpretacje. Vol. 4. Edited by Motyka, G. Warsaw: Inst. Pamięci Narodowej.

Joyce, A., 2017. "Dying out": conversion and the complexity of neighbourliness on the Polish Belarussian border. History and Anthropology, 28 (1): pp.110-130. 
Kaczynski 2011. "Raport o Stanie Rzeczypospolitej” available via

http://wpolityce.pl/polityka/111772-jaroslaw-kaczynski-raport-o-stanie-rzeczypospolitejtylko-u-nas-fragmenty-programowej-publikacji-prezesa-pis

Keleher, S. 1995. "Trapped Between Two Churches: Orthodox and Greek-Catholics in Poland" Religion, State and Society, 23(4): 365-371

Kersten, K. 1991. The Establishment of Communist Rule in Poland, 1943-1948. Translated by Micgiel, J. \& M.H. Bernhard. Berkeley: University of California Press.

Knudsen, I.H. and Frederiksen, M.D. eds., 2015. Ethnographies of grey zones in Eastern Europe: Relations, borders and invisibilities. London: Anthem Press.

Meyer, M. (2012). "Placing and tracing absence: A material culture of the immaterial". Journal of Material Culture, 17(1), 103-110.

Mich, W. 1994. Obcy w Polskin Domu: nacjonalistyczne koncepcje rozwiązania problemu mniejszości naradowych 1918-1939. Lublin: Wydawnictwo Uniwersytetu Marii CurieSkłodowskiej.

Misiło, E. 2013. Akcja Wisła 1947. Dokumenty i Materiały. Warsaw: Archiwum Ukraińskie.

Napolitano, V 2015. “Anthropology and Traces”. Anthropological Theory 15(1): 47-67

Navaro- Yashin, Y 2009. "Affective spaces, melancholic objects: ruination and the production of anthropological knowledge." Journal of the Royal Anthropological Institute 15(1): 1-18.

Navaro-Yashin, Y. 2012. The make-believe space: affective geography in a post-war polity. Duke University Press. 
Nichanian, Marc. The historiographic perversion. New York: Columbia University Press, 2009.

O'Neill, K.L., (2013). Beyond Broken: affective spaces and the study of American religion. Journal of the American Academy of Religion, 81(4): 1093-1116.

Papierzyńska-Turek, M. 1989. Między Tradycją a Rzeczywistością: Państwo Wobec Prawosławia 1918-1939. Warsaw: PWN.

Pine, F. "Memories of Movement and the Stillness of Place: kinship memory in the Polish highlands." In J. Carsten ed. Ghosts of memory: Essays on remembrance and relatedness. Oxford: Wiley-Blackwell, 2007: 104-125.

Pine, F. and Y. Navaro-Yashin. In Conversation at Thinking Memory Through Space: Materiality, Representation and Imagination. Goldsmiths University of London, 2013.

Piotrowski, T. 1998. Poland's Holocaust: Ethnic Strife, Collaboration with Occupying Forces and Genocide in the Second Republic, 1918-1947 London: McFarland \& Company. Poklosie, 2012. Menemsha Films; Monolith Films, Poland. Directed by Pasikowski, W.

Reeves, M., 2014. Border work: spatial lives of the state in rural Central Asia. New York: Cornell University Press.

Róża, 2011. Monolith Films, Poland. Directed by Smarzowski, W.

Rutherford, D., 2016. Affect theory and the empirical. Annual Review of Anthropology, 45, pp. 285-300. 
Rylko-Bauer, B, 2005. "Lessons about Humanity and Survival from My Mother and from the Holocaust". In Anthropological Quarterly 78(1): 11-41.

Sawicka 2016 "How PiS Re-Interprets Polish History” in Polityka Insight, via http://www.politykainsight.pl/en/politics/politicsofmemory/1668996,1,how-pis-re-interpretspolish-history.read

Snyder, T. "“To Resolve the Ukrainian Problem Once and for All”: The Ethnic Cleansing of Ukrainians in Poland, 1943-1947." Journal of Cold War Studies 1, no. 2 (1999): 86-120.

Snyder, T. The Reconstruction of Nations. New Haven: Yale University Press, 2003

Spector, S, and G Wigoder, eds. The Encyclopaedia of Jewish Life Before and During the Holocaust: K-Sered. Vol. 2. NYU Press, 2001.

Taussig, Michael. "Dying is an art, like everything else." Critical Inquiry 28.1 (2001): 305316.

Trouillot, M. R. 1995. Silencing the past: Power and the production of History, Boston: Beacon Press

Wandycz, P. S. 1975. The lands of partitioned Poland, 1795-1918. Washington: University of Washington Press.

Weinryb, B. The Jews of Poland: a social and economic history of the Jewish community in Poland from 1100 to 1800. Philadelphia: Jewish Publication Society, 1973.

Witeska-Mlynarczyk, A. Evoking Polish Memory: State, self and the Communist past in transition. Frankfurt: Peter Lang Edition, 2013. 
Wylegała, Anna. "The absent 'Others': A comparative study of memories of displacement in Poland and Ukraine." Memory Studies 8.4 (2015): 470-486.

Zarycki, T. 2013. "Debating Soviet Imperialism in Contemporary Poland: On the Polish uses of the Post-Colonial Theory and Their Contexts" In Empire De/Centred New Spatial Histories of Russia and the Soviet Union. Edited by S. Turoma, M. Waldstein Kupovykh. Surrey: Ashgate Publishing.

Websites:

http://www.jewishgen.org/Yizkor/koden/koden.html

http://kehilalinks.jewishgen.org/koden/

http://www.iajgsjewishcemeteryproject.org/poland/koden.html

http://www.kirkuty.xip.pl/koden.htm

http://www.sztetl.org.pl/en/city/koden/

http://www.poland.travel/en/regions/the-lubelskie-voivodship-the-bug-river-trail

https://news.artnet.com/art-world/director-polish-culture-institute-berlin-fired-jewish-content$\underline{771281}$

http://wyborcza.pl/7,75398,20437437,wybitni-historycy-zajmujacy-sie-zaglada-protestuja$\underline{\text { szokujace.html }}$

$\underline{\text { http://wyborcza.pl/1,75398,19653250,msz-pyta-prokurature-o-prof-tomasza-grossa.html }}$ 
http://wyborcza.pl/1,76842,19622070,ziobro-potwierdza-beda-kary-za-mowienie-o-polskich-

obozach.html

https://www.foreignaffairs.com/articles/hungary/2018-02-14/rewriting-history-eastern-europe

https://www.politico.eu/article/polands-wwii-museum-under-political-bombardment/

https://www.politico.eu/article/poland-law-and-justice-retreats-on-controversial-laws/

https:/www.washingtonpost.com/news/monkey-cage/wp/2018/02/27/polands-right-wing-

government-is-rewriting-history-with-itself-as-hero/

\footnotetext{
${ }^{1}$ Akcja Wisła was a state organized resettlement program begun post World War II.

${ }^{2}$ Throughout this article, I will follow the local Polish practice of referring to Eastern Orthodox Christianity as Orthodoxy (Prawostawny)

${ }^{3}$ While I focus on Navaro-Yashin's work here there is a larger canon of "affect theory" that could be deployed, particularly the wok of O'Neill (2013). However, as Rutherford (2016) and Seigworth and Gregg (2009) have pointed out the field of affect theory covers a lot of theoretical, thematic and disciplinary ground, so this article contains itself to a very small section of the work.

${ }^{4}$ The Law and Justice Party

${ }^{5}$ See this Washington Post article from the end of February https://www.washingtonpost.com/news/monkeycage/wp/2018/02/27/polands-right-wing-government-is-rewriting-history-with-itself-ashero/?noredirect $=$ on\&utm term $=.8759836 \mathrm{e} 915 \mathrm{c}$

${ }^{6}$ Civic Platform Party

${ }^{7}$ Knudsen \& Frederiksen's edited volume "Ethnographies of Grey Zones" (2015) takes a similar approach to looking at the border through its inhabitants and through the everyday work of small state actors.

${ }^{8}$ I have spoken at length about the history of the "Kresy" region in an earlier article: (Joyce 2017)

${ }^{9} \mathrm{http}$ ://www.poland.travel/en/regions/the-lubelskie-voivodship-the-bug-river-trail

${ }^{10}$ See Charnysh \& Finkel 2018 for the most recent summery of changes to national remembrance laws.

${ }^{11} \mathrm{https}$ ://www.politico.eu/article/poland-law-and-justice-retreats-on-controversial-laws/

12 http://wyborcza.pl/1,76842,19622070,ziobro-potwierdza-beda-kary-za-mowienie-o-polskich-obozach.html

13 http://wyborcza.pl/7,75398,20437437,wybitni-historycy-zajmujacy-sie-zaglada-protestuja-szokujace.html they also include growing call to strip Jan Gross author of "The Neighbors" of his Order of Merit http://wyborcza.pl/1,75398,19653250,msz-pyta-prokurature-o-prof-tomasza-grossa.html and the dismissal of Katarzyna Wielga-Skolimowska from the Polish Institute in Berlin for featuring Jewish-Polish relations too prominently, promoting the "culture of shame" rather than Polish self-respect https://news.artnet.com/artworld/director-polish-culture-institute-berlin-fired-jewish-content-771281

${ }^{14} \mathrm{https}$ ://www.politico.eu/article/polands-wwii-museum-under-political-bombardment/

${ }^{15}$ List of sites that have information on the Jewish history of Kodeń http://www.sztetl.org.pl/en/city/koden/ ; http://www.kirkuty.xip.pl/koden.htm; http://www.iajgsjewishcemeteryproject.org/poland/koden.html ; http://kehilalinks.jewishgen.org/koden/; http://www.jewishgen.org/Yizkor/koden/koden.html

${ }^{16}$ Both Rylko-Bauer and Bourgois' articles in the Anthropological Quarterly special issue "Bridging the Past into the Present: Family narratives of Holocaust, Exile and Diaspora" wrestle with this dynamic of telling and not telling about the Holocaust (2005). In both the anthropologists are speaking with parents willing to speak of the Holocaust, but eager to shield them from the worst of the stories, or to downplay their own statue as "true Holocaust survivors". 17 The Masurians were classified as ethnically German after World War II and many were relocated as part of Akcja Wisła
} 